\title{
Water management alters phytoplankton and zooplankton communities in Ebro delta coastal lagoons
}

\author{
Patricia Prado*, Nuno Caiola and Carles Ibáñez \\ IRTA Aquatic Ecosystems. Ctra. Poble Nou km 5.5. 43540 Sant Carles de la Ràpita (Tarragona), Spain. \\ *Corresponding author: patricia.prado@irta.cat
}

Received: 04/04/16

Accepted: 20/02/17

\begin{abstract}
Water management alters phytoplankton and zooplankton communities in Ebro delta coastal lagoons

Coastal lagoons of the Ebro Delta (Catalonia, Spain) have been subjected to historical reductions of their hydrological connections with the sea and to freshwater discharges from rice agriculture, with a more recent switch to freshwater inputs from the Ebro River to improve their trophic state. As a result, the seasonal salinity regime in three formerly connected coastal lagoons varies, being polyhaline to oligohaline from May to November but polyhaline in winter. We evaluate the effects of current water management on the abundance and community structure of phytoplankton and zooplankton within the three lagoons and assess the contribution of environmental variables in February and August. Temporal variation evidenced the typical increase in phytoplankton and zooplankton abundance from winter to summer. However, contrasting August salinities among lagoons showed opposite effects in the two communities, with higher abundance of total zooplankton and lower abundance of total phytoplankton at higher salinities. Besides, each lagoon displayed distinctive groups of taxa and showed important temporal differences. Temperature and salinity were the most important factors determining the structure of assemblages (ca. $60 \%$ and $72 \%$ of phytoplankton and zooplankton variance, respectively). Compared to the period of agricultural runoff ca. $30 \mathrm{yrs}$ ago, our results show an important decrease in the overall abundance of phytoplankton $(>50 \%)$, whereas zooplankton abundances are ca. 6 times higher. However, environmental variability associated with the salinity gradient appears to be responsible for observed changes in the abundance and structure of planktonic assemblages.
\end{abstract}

Key words: Salinity alteration, seasonality, diatoms, dinoflagellates Canuella perplexa, Calanipeda aequadulcis.

\section{RESUMEN}

\section{La gestión hídrica altera las comunidades de fitoplancton y zooplancton de las lagunas costeras del Delta del Ebro}

Las lagunas costeras del Delta del Ebro (Cataluña, España) han sido objeto de reducciones históricas en el número de sus conexiones hidrológicas con el mar. Además, han sido sometidas a persistentes vertidos de agua dulce procedentes de la agricultura del arroz, que más recientemente, han sido sustituidas por agua del Río Ebro para mejorar su estado trófico. Como consecuencia, el régimen estacional de salinidad en tres lagunas costeras previamente interconectadas varía entre polihalino-oligohalino de mayo a noviembre, y se mantiene polihalino durante el invierno. En este trabajo, se evaluaron los efectos de la gestión hídrica en la abundancia y composición de fitoplancton y zooplancton, así como la contribución de las variables ambientales en la estructura de las comunidades durante los meses de febrero y agosto. La variación temporal mostró el típico aumento en la abundancia de fitoplancton y zooplancton de invierno a verano. En cambio, la variabilidad de la salinidad entre lagunas durante el mes de agosto mostró efectos opuestos en las dos comunidades; observándose una mayor abundancia de zooplancton y menor abundancia de fitoplancton a mayor salinidad. Además, cada laguna mostró distintas agrupaciones taxonómicas así como importantes diferencias temporales. La temperatura y la salinidad fueron los factores más importantes en determinar la estructura de las comunidades (ca. $60 \%$ y $72 \%$ de la varianza del fitoplancton y zooplancton, respectivamente). Comparado con el período de contaminación agrícola hace ca. 30 años, nuestros resultados muestran una importante disminución en la abundancia total de fitoplancton (>50\%), mientras que las abundancias de zooplancton son ca. 6 veces mayores. Sin embargo, la mayor variabilidad ambiental derivada del gradiente de salinidad parece ser responsable de los cambios en la abundancia y estructura de las comunidades planctónicas.

Palabras clave: Alteración salina, estacionalidad, diatomeas, dinoflagelados, Canuella perplexa, Calanipeda aequadulcis. 


\section{INTRODUCTION}

Understanding the processes that regulate phytoplankton and zooplankton abundances and growth rates is a central issue in aquatic biology. An increase in the frequency and duration of phytoplankton blooms, and changes in the species involved, can lead to a reduction in light penetration and oxygen depletion at depth, causing substantial perturbations that cascade through the entire food web structure and alter ecosystem functioning (Bodeanu, 1993). Fluctuations in the abundance and composition of zooplankton can affect the recruitment of target fisheries species and determine the structure and function of the food-web in coastal and marine ecosystems (Heath, 2005). Human activities such as agricultural practices, industrial processes, and urban development have dramatically altered the hydrology and the amounts of anthropogenic materials delivered to coastal areas, impacting the natural processes involved in the regulation of planktonic communities (Lotze et al., 2003). These alterations may be particularly important in coastal lagoons, due to limited flushing and reduced water renovation, leading to the accumulation of organic matter, nutrients, and anthropogenic contaminants (e.g., Rigollet et al., 2004).

Mediterranean lagoon systems are often said to host homogeneous communities, the so-called euryhaline and eurythermal biocenoses, unlike the biological gradients proposed for estuarine systems (Pérez-Ruzafa et al., 2011). Yet they are seldom closed systems and can be subjected to significant horizontal salinity gradients due to tides and freshwater runoff, as well as vertical gradients due to the evaporation caused by solar radiation (Kjerfve \& Magill, 1989), which may also influence biological patterns. Phytoplankton communities in these systems follow a seasonal dynamics, with lowest growth rates during the winter period, due to reduced solar irradiance and vertical wind mixing, and peaks during the spring-summer seasons, following enhanced light conditions and higher photosynthetic activity (Gilabert, 2001; Nuccio et al., 2003). Chlorophyll- $a$ concentrations have been found to be strongly associated with levels of total nitrogen and total phosphorous; the more oligotrophic lagoons appearing to be phosphorus-limited, with a tendency towards the development of nitrogen limitation as eutrophication increases (Souchu et al., 2010). In regard to salinity, species are often characterized as euryhaline and capable of adapting to the high variability of the natural media (Badylak \& Phlips, 2004). Yet euryhaline phytoplankton may also attain optimal growth at a certain salinity value or range, and decrease continuously from this optimum toward higher or lower salinities (e.g., Grzebyk \& Berland, 1996; Roubeix \& Lancelot, 2005), which may result in distinctive patterns of species abundances along environmental gradients. For instance, Gasiūnaite et al. (2005) compiled phytoplankton successional data from seven different lagoons and semi-enclosed basins and were able to identify community groupings indicative of salinity, trophic status, and climatic conditions.

For zooplankton, high peaks linked to phytoplankton chlorophyll- $a$ maxima suggest that they might experience food limitation (Sei et al., 1996) and hence be influenced by the same factors that control planktonic primary production in coastal lagoons. Changes in habitat temperature have been shown to explain a large component of the variations in metabolic rates (oxygen $\left(\mathrm{O}_{2}\right)$ uptake, ammonia and P excretion; Ikeda, 1985) and account for the remarkable seasonal and latitudinal variation in zooplankton size and species diversity across cold-temperate and Mediterranean coastal lagoons (Brucet et al., 2010; Gilabert, 2001). As in the case of phytoplankton, the zooplankton taxa common in Mediterranean coastal lagoons are euryhaline or tolerant of intermediate salinity (Badosa et al., 2007; Brucet et al., 2009). Nevertheless, tolerance to salinity has been shown to be a central factor controlling the abundance and composition of zooplankton (Brucet et al., 2009), and its importance is expected to increase in the future, due to the enhanced evaporation associated with climate change (Schallenberg et al., 2003; Brucet et al., 2010). Other abiotic elements, such as wind, precipitation, turbidity and hydrology, may also influence the 
seasonal availability of zooplankton, as shown in various coastal Mediterranean lagoons (e.g. Gi-, labert, 2001; Badosa et al., 2007). For instance, food availability for zooplankton tends to decline with siltation due to light limitation of the primary production (PP), and the interference of sediment particles with the filter feeding processes (Hart, 1988).

In the Ebro Delta (Southern Catalonia, NW Mediterranean) ca. $70 \%$ of the total surface is devoted to rice cultivation and coastal lagoons have persistently received agricultural wastewater, in variable amounts, over the last 150 years (no biological data from the pre-impact period is available). From the 1960 s to late 1980s the lagoons received large amounts of drainage water from the rice fields with high contents of fertilizers and pesticides, but seasonal salinity conditions were similar across all lagoons (oligohaline to mesohaline-polyhaline; Comín, 1984). During this period, submerged macrophytes in the lagoons declined by over $80 \%$ and the system became dominated by phytoplankton, reaching average values of up to $10^{4}-10^{5}$ cells $/ \mathrm{ml}$ (Comín, 1984). The hydrological regime also seems to have been the most important factor driving zooplankton composition of, with some variability in abundance patterns possibly linked to: (1) differences in plant biomass and turbidity and (2) to phytoplankton peaks during the winter period, when salinities were higher or food was more limiting (Menéndez \& Comín, 1986). Around 1990, the regional government and Natural Park authorities started a new water management strategy for the lagoons, in which most of the seasonal wastewater inputs from rice fields were replaced by freshwater inputs from the Ebro River during the same period (with lower organic matter and nutrients). However, the freshwater inputs were mostly diverted into the Clot lagoon, and to lesser extent into the Encanyissada and the Tancada lagoons, which also have more connections with the sea, thus resulting in a strong salinity gradient (oligohaline to polyhaline) during the summer, and polyhaline during the winter (Prado et al., 2013a). Hence, despite better water quality, seasonal freshwater discharge determined the abundance and composition of submerged macrophytes and macrofaunal assemblages (Prado et al., 2013a; 2014a), and altered the trophic dynamics of fish species (Prado et al., 2014b).

The aim of this study was to assess the extent of potential alterations in the planktonic communities induced by current water management practices during the rice growth season. To this end, we conducted sampling in three coastal lagoons subjected to contrasting salinity regimes from May to November (relatively stable since at least 2007; Prado et al., 2013a) but with similar ranges during the rest of the year (in months with and without freshwater inflows, respectively) and we evaluated: (1) temporal patterns of variability (summer and winter) in the abundance, and community structure of phytoplankton and zooplankton; and (2) the relative importance of salinity and other environmental (e.g., $\mathrm{T}\left({ }^{\circ} \mathrm{C}\right)$, and $\mathrm{pH}$ ) and biotic variables (e.g., biomass of submerged plants) on the abundance and composition of planktonic communities. In addition, we made comparisons with community data available from 30 years ago under a different water management regime.

\section{MATERIALS AND METHODS}

\section{Study sites}

The study took place in three coastal lagoons of the Ebro Delta, Spain -the Clot, Encanyissada and Tancada lagoons (Fig. 1)- which receive freshwater inflows from the Ebro River from April-May till November as well as marine water through canals connecting with the sea. As a result, current salinity ranges are 3.6 to 11.6 in the Clot lagoon, 12.5 to 27.1 in Encanyissada, and 18.6 to 28.1 in Tancada (see Prado et al., 2013a for further details). Hence, given that planktonic communities are short-lived, sampling was constricted to late February and late August 2010 (which are respectively the months of highest salinity and lowest variability across lagoons, and of lowest salinity and highest variability across lagoons) in order to assess the effects of altered salinity conditions vs. other commonly reported 
variables such as temperature and plant biomass (see later). In each lagoon, study sites were selected where salinity had been monitored seasonally since 2007 . In total, 5 sites in the Encanyissada lagoon (E1 to E5) were compared with 5 sites in the Clot (C1 to $\mathrm{C} 5)$ and 5 in the Tancada lagoon (T1 to T5) (Fig. 1). Adjacent sites in each lagoon were ca. $300 \mathrm{~m}$ apart. The average water depth in all the lagoons was $80-90 \mathrm{~cm}$.

The Encanyissada lagoon is the largest in size (418 ha) and is connected to the Alfacs Bay through a natural outlet and to the Clot lagoon (56 ha) through an artificial channel. The Tancada lagoon (185 ha) is connected to Alfacs bay through one large and two narrow artificial canals (Fig. 1). The lagoons are separated from the Ebro River by ca. 5.5-6.5 km and historically did not receive freshwater inputs until the beginning of agricultural practices. Before human intervention ca. 150 years ago, the area contained a single vast lagoon highly connected to the Alfacs Bay through a salt marsh area, but extensive drainage for rice field creation resulted on isolation from the sea and separation into three different water bodies.

\section{Sampling and laboratory processing}

A single phytoplankton sample was collected at each lagoon site $(N=5)$ in February and August. This sampling approach, based in Sournia (1978), is nowadays commonly used in phytoplankton monitoring in Ebro Delta bays (M. Menendez, pers. communication). The entire water column (ca.80 to $90 \mathrm{~cm}$ depth) was sampled with a 2-liter Niskin bottle. Samples were kept in $250 \mathrm{ml}$ dark glass bottles and kept refrigerated at $4{ }^{\circ} \mathrm{C}$. Once in the lab, samples were filtered through a $44 \mu \mathrm{m}$ gauze (Gilabert, 2001) for separation of zooplankton and other large suspended particles, and subdivided into two $100 \mathrm{ml}$

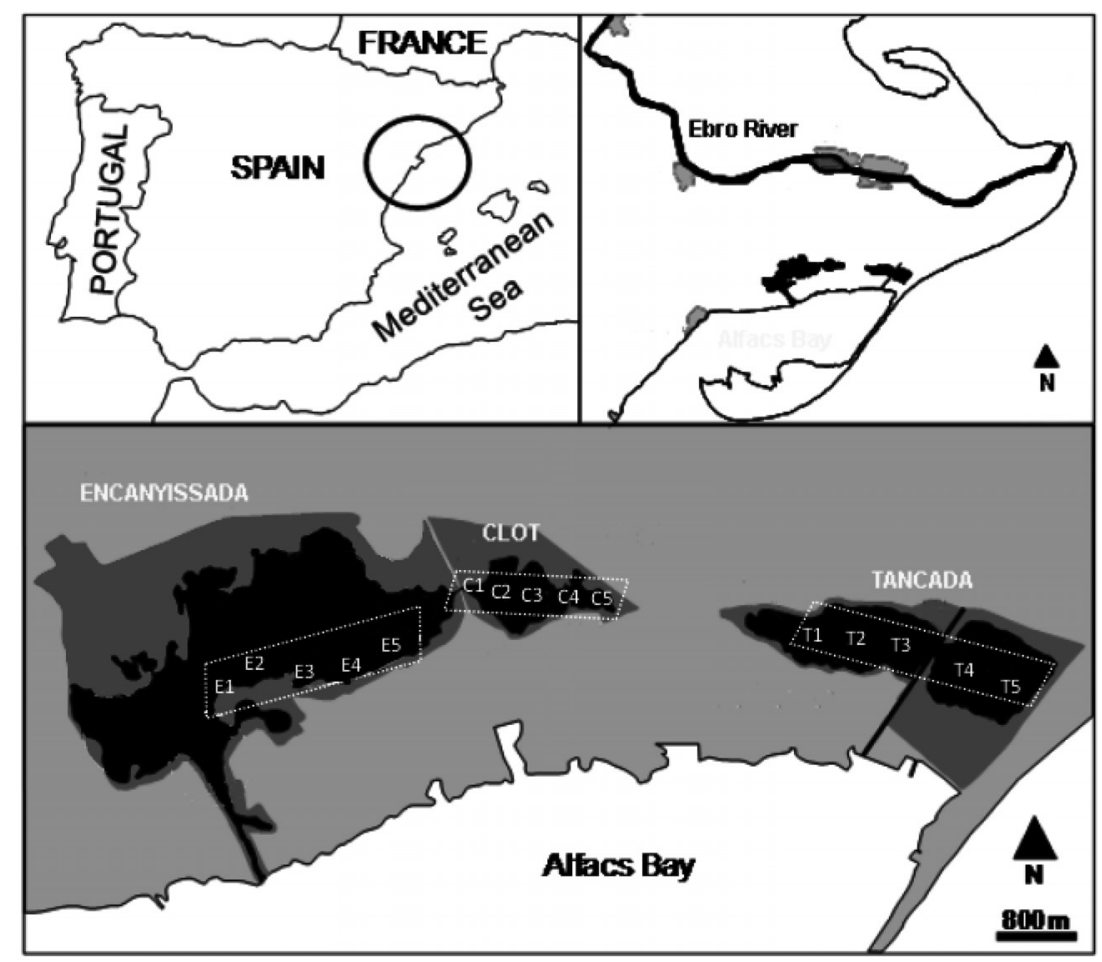

Figure 1. Map of the three studied coastal lagoons showing the position of the sampling sites in the Encanyissada (E1, E2, E3, E4, and E5), Clot (C1, C2, C3, C4, and C5) and Tancada (T1, T2, T3, T4, and, T5) lagoons. Mapa de last res lagunas de estudio indicando la posición de los puntos de muestreo en la Encanyissada (E1, E2, E3, E4, and E5), Clot (C1, C2, C3, C4, and C5) y Tancada $(T 1, T 2, T 3, T 4$, and, T5). 
bottles. The first was fixed with $1 \%$ acidic Lugol's solution and $0.25 \%$ glutaraldehyde and kept refrigerated at $4{ }^{\circ} \mathrm{C}$ for later examination under the microscope, and the second one was fixed with $1 \%$ acidic Lugol's solution and $1 \%$ buffered formalin and stored for eventual backup purposes. Picoplankton $(0.2-2 \mu \mathrm{m})$ was not included in this study.

Samples were homogenized and allowed to sediment overnight in $50 \mathrm{ml}$ Utermöhl settling chambers (Hydro-Bios combined plate chambers) and then cells were counted under an inverted microscope. Very abundant groups such as Bacillariophyceae, thecate and athecate Dinophyceae and nanoflagellates were counted in two transects at $\times 40$ magnification $\left(14.04 \mathrm{~mm}^{2}\right.$ each), and then numbers extrapolated to the surface in the entire plate chamber. For the rest of the community, cells were counted in the entire plate at $\times 20$ magnification, and classified into class groups (e.g., Dictyochophyceae, Prymnesiophyceae, etc.).

Zooplankton samples were also collected from the entire water column with a 10-liter Niskin bottle ( $n=3$ per site and sampling period). Each replicate was filtered in situ through a $44 \mu \mathrm{m}$ mesh net (thus also including most of the microzooplankton size range) and preserved in $100 \mathrm{ml}$ containers with $4 \%$ buffered formalin. In the laboratory, samples were concentrated into volumes of $10 \mathrm{ml}$, again with a $44 \mu \mathrm{m}$ mesh, from which a $3 \mathrm{ml}$ homogeneous aliquot was taken with a Hensen-Stempel pipette for observation under the inverted microscope. When the number of individuals of the most abundant taxa exceeded 100, only the aliquot was counted (Brucet et al., 2009), but otherwise the whole sample $(10 \mathrm{ml})$ was observed. For adult copepods, and copepodite, individuals were identified to species level. All other zooplankton were identified to broader taxonomic groups, for example, Bivalvia, Polychaeta, Gastropoda, Foraminifera, Ostracoda, Branchiopoda (Cladocera), Rotifera, and Ciliates.

Abundances were estimated from the added values of each taxon per sample and expressed in numbers of cells per ml (total phytoplankton) or number of individuals per L (total zooplankton). These abundance values were then used for assessing differences in the compositional patterns of planktonic communities across lagoons and sampling periods.

\section{Environmental and biotic variables}

Salinity, T $\left({ }^{\circ} \mathrm{C}\right), \%$ dissolved oxygen (DO), and $\mathrm{pH}$ were recorded using a multiparameter probe YSY 6600 V2. Distance to shore was estimated as the distance in $\mathrm{m}$ from the GPS point at each sampling site to the nearest shoreline using Google Earth. Exposure to the two dominant lo-

Table 1. Results of two-way ANOVA test for phytoplankton and three-way ANOVA test for zooplankton (Abundance in cells/ml, and individuals/L, respectively). Significant results are indicated in bold. $\mathrm{E}=$ Encanyissada, $\mathrm{C}=\mathrm{Clot}, \mathrm{T}=\mathrm{Tancada}, \mathrm{Feb}=\mathrm{February}$, Aug= August. Resultados de la ANOVA de dos vías para fitoplancton y de la ANOVA de tres vías para zooplancton (Abundancias en No. cel/ml, y No. ind/L, respectivamente). Los resultados significativos se indican en negrita.

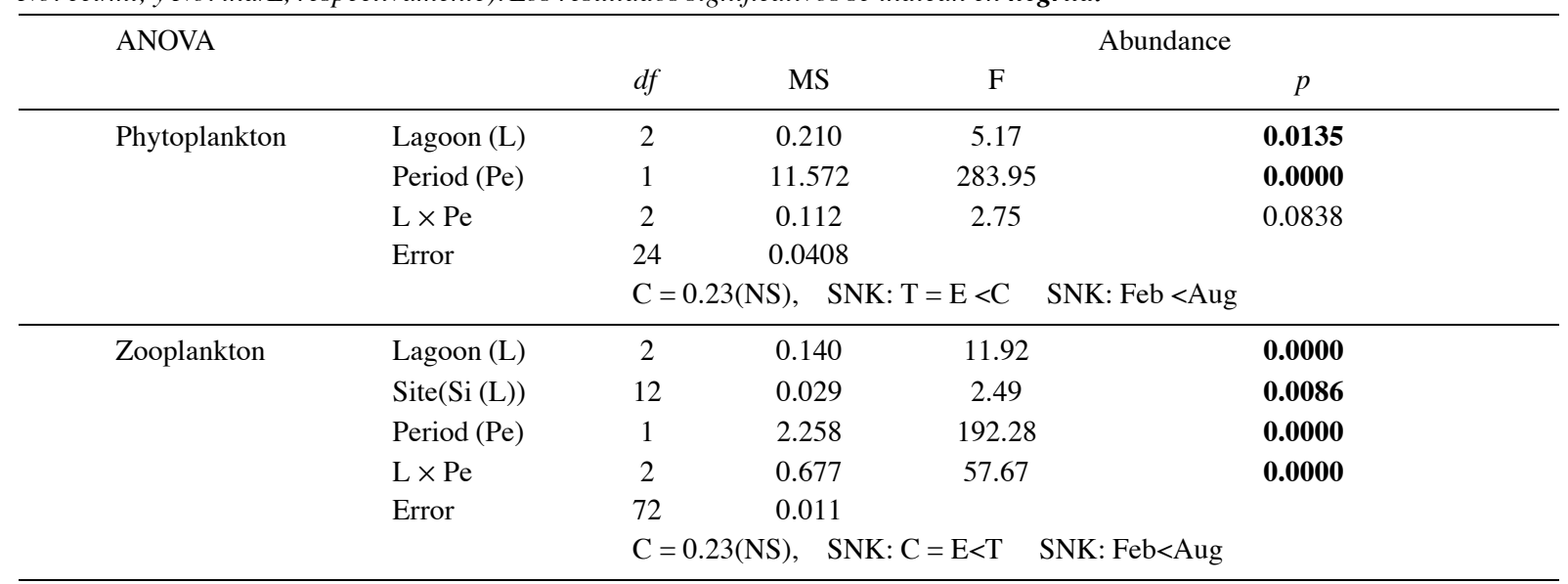


cal winds (Mistral (N): 337 to $24^{\circ}$ and Garbí (SW): 180 to 210 ) was also estimated as the distance from the GPS site point at the wind angle (lower and upper limit) to the nearest point of the shoreline along the axis of wind direction but in opposite sense. Plant biomass per $\mathrm{m}^{2}$ was available from Prado et al., (2013a). Grain sizes were determined from the top $5 \mathrm{~cm}$ of sediments collected using a $4.2 \mathrm{~cm}$ diameter plastic container. After drying, samples were separated into three major grain sizes (gravel: 8-1 mm; sand: <1 mm-125 mm; silts: $63 \mathrm{~mm}$ ), and then weighed and expressed as a percentage of the mass sample. The three sediment fractions were later reassembled and incinerated for determination of organic matter (OM) content. Water samples were collected at each site at each site and time and kept refrigerated at $-20{ }^{\circ} \mathrm{C}$ until determination of dissolved nutrients contents (ammonium $\left(\mathrm{N}-\mathrm{NH}_{4}\right)$, nitrate $\left(\mathrm{N}-\mathrm{NO}_{3}\right)$, nitrite $\left(\mathrm{N}-\mathrm{NO}_{2}\right)$, and phosphate $\left(\mathrm{P}-\mathrm{PO}_{4}\right)$ ) following the Koroleff (1977) method.

\section{Statistical analyses}

For total phytoplankton, differences in abundance across lagoon and sampling periods were investigated with a 2-way ANOVA: Lagoon (L)
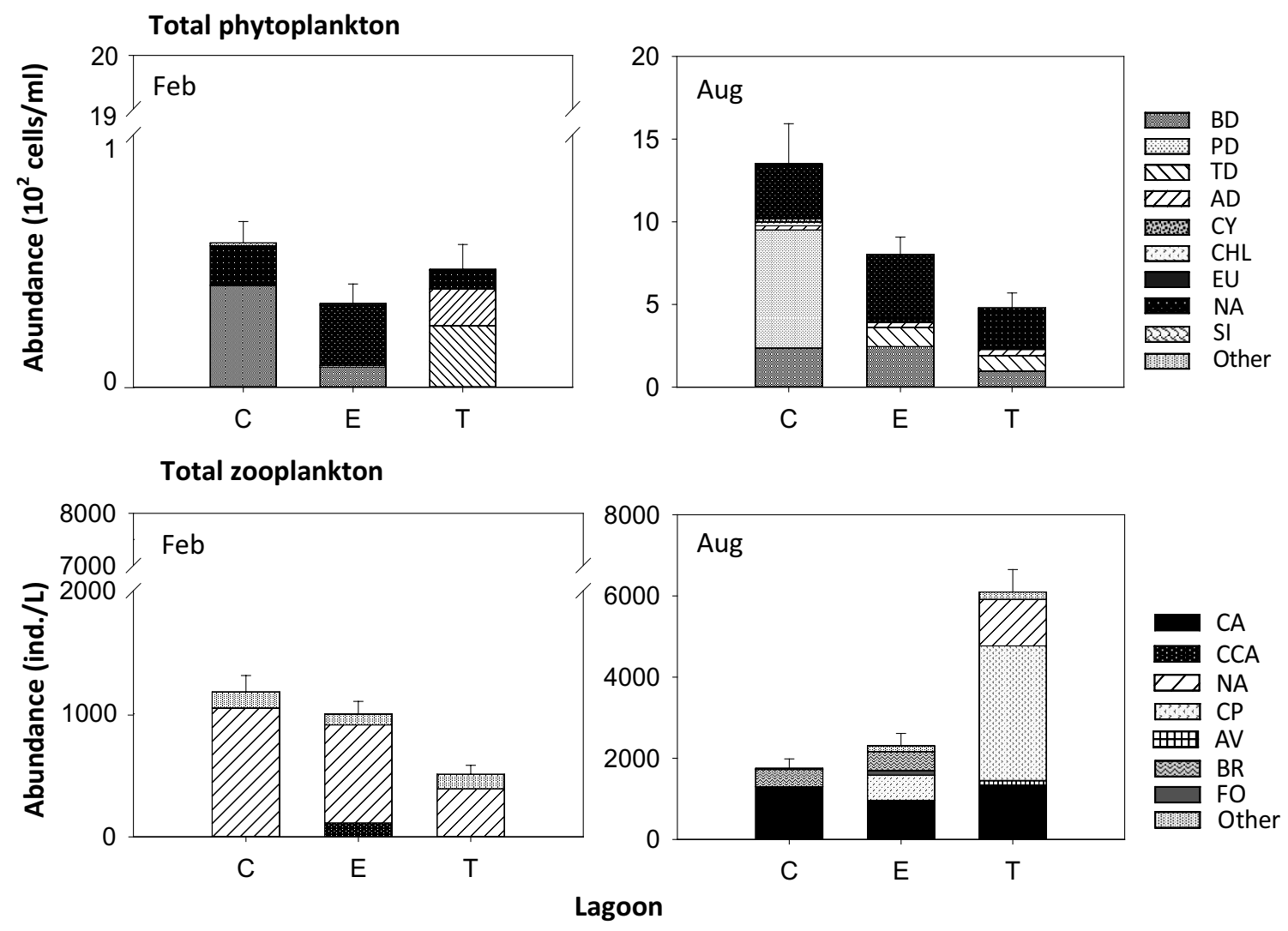

Figure 2. Seasonal variability in the abundance of phytoplankton (cells/ml) and (c-d) zooplankton taxa (individuals/L) across lagoons. For zooplankton/zooplancton: $\mathrm{CA}=$ Calanipeda aequadulcis; $\mathrm{CCA}=$ copepodite C. aequadulcis; $\mathrm{AV}=$ Acanthocyclops vernalis $; \mathrm{CP}=$ Canuella perplexa $; \mathrm{NA}=$ nauplii stages $; \mathrm{FO}=$ foraminifera; $\mathrm{BR}=$ Branchiopoda. Phytoplankton and zooplankton taxa with abundances $1 \mathrm{cell} / \mathrm{ml}$ and $<100$ ind./L, respectively, have been pooled and indicated as "Other". For phytoplankton/fitoplancton: $\mathrm{BD}=$ benthic diatoms; $\mathrm{PD}=$ planktonic diatoms; $\mathrm{TD}=$ thecate dinoflagellates; $\mathrm{AD}$ : athecate dinoflagellates; $\mathrm{SI}=$ silicoflagellates; $\mathrm{CY}=$ Cianophyta $; \mathrm{CHL}=$ Chlorophyta $; \mathrm{EU}=$ Euglenophyta $; \mathrm{NA}=$ nanoflagellates. Variabilidad estacional en la abundancia de fitoplancton (cel/ml) y zooplancton (ind./L) entre lagunas. Los taxones de fitoplancton y zooplancton presentes en abundancias $<1$ cel./ml y $<100$ ind./L, respectivamente, se presentan agrupados e indicados como "Otros". 
(3 levels: Clot, Encanyissada, and Tancada; fixed factor); and Period (Pe) (2 levels: February, and August; fixed factor).

For total zooplankton, differences in the abundance of individuals were investigated with a 3way ANOVA: L-Lagoon (3 levels: Clot, Encanyissada, and Tancada; fixed factor); Si-Site (5 levels, random factor nested in lagoon); and SeSeason (2 levels: February, and August; fixed factor). All data were transformed when necessary to meet ANOVA assumptions of normality (Kolmogorov Smirnov test) and homogeneity of variances (Cochran's test). Significant factor groupings were further investigated with SNK (Student-Newman-Keuls) post-hoc tests. All ANOVA analyses were conducted with the Statistica software package.

Spatial patterns of phytoplankton and zooplankton assemblages among lagoons and within the Encanyissada lagoon were investigated with the PRIMER v6 software package. nMDS ordinations and ANOSIM analyses were used to examine differences among lagoons and seasons. In addition, SIMPER analyses, also from PRIMER, were used to investigate which taxa made the largest contributions to both similarities and dissimilarities within and among factor groups, respectively.

Individual phytoplankton and zooplankton taxa were related to environmental (temperature, salinity, depth, local winds, distance to shore, DO, and nutrients) and biotic variables (plant biomass, and abundance of phytoplankton; the later only in zooplankton analyses) using CCA in the CANOCO software package. In all multivariate analyses, taxa data were $\log (x+1)$ transformed.

\section{RESULTS}

\section{Taxa abundances}

For phytoplankton, observed taxa included: benthic and planktonic Bacillariophyceae (diatoms), thecate and athecate Dinophyceae (dinoflagellates), Dictyochophyceae (silicoflagellates), Prymnesiophyceae (coccolithophorids), Synurophyceae, Cyanophyceae, Chrysophyceae, Chlorophyceae, Euglenophyceae, nanoflagellates (Cryptophyceae), and resting cysts. The total abundance of phytoplankton showed significant effects of Lagoon and Season (Table 1). In SNK, the Clot lagoon showed significantly higher numbers of cells per ml compared to the Encanyissada and Tancada lagoons, and numbers were much higher in August than in February (Fig. 2).

For zooplankton, taxa found included: Copepoda (adults and copepodita of Calanipeda aequadulcis, adults of Acartia tonsa, Acanthocy-
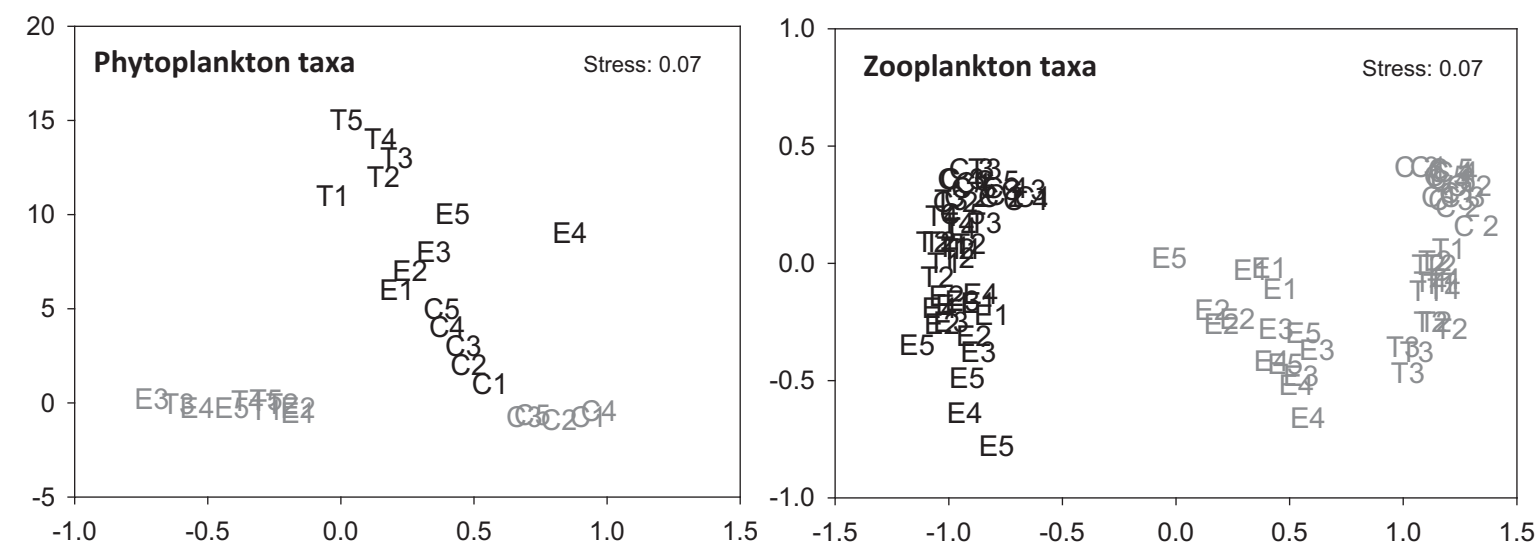

Figure 3. nMDS ordination showing differences in phytoplankton and zooplankton assemblages across lagoons and seasons. February samples are indicated in black, and August samples in grey. nMDS mostrando las diferencias en las comunidades de fitoplancton y zooplancton en las distintas lagunas y estaciones. Las muestras de febrero se indican en negro y las de agosto en gris. 
clops vernalis, Cletocamptus retrogressus, Bryocamptus sp., Canuella perplexa, and indeterminate nauplii stages), bivalve larvae, polychaete larvae (Phyllodocidae), Gastropoda larvae (Hydrobidae), Foraminifera, Ostracoda (Loxoconcha), Branchiopoda (Cladocera), Rotifera, and Ciliates. The total abundance of zooplankton displayed significant effects for all factors and interactions investigated (Table 1). The overall number of individuals was much higher in the Tancada lagoon than in the Encanyissada and Clot, particularly in August, although temporal differences were also more marked in the Tancada lagoon (Fig. 2B).

\section{Patterns of assemblages}

For phytoplankton taxa, the results of nMDS ordination showed different groupings for samples belonging to each lagoon and sampling period, which were further confirmed by ANOSIM results (Fig. 3, Table 2). In pairwise comparisons and SIMPER analyses, the largest $\mathrm{R}$ value and dissimilarity rates occurred both between sampling period and between the Tancada and Clot lagoons, which had the largest differences in salinity and were displayed further apart in the nMDS ordination (Fig. 3). Dinoflagellates (thecate and athecate) occurred at high abundance in the Tancada lagoon, intermediate values in
Encanyissada, and lowest values in Clot (37-47\% of dissimilarities between lagoons). In contrast, diatoms (particularly benthic), displayed the opposite pattern, with highest abundance in Clot, intermediate in Encanyissada, and lowest in Tancada (38 to 44\% of dissimilarities). Nanoflagellates were present in similar abundances in the Clot and Tancada lagoons, and displayed highest values in Encanyissada (8-19\% of dissimilarities).Temporally, differences were also mostly explained by variability in the abundance of these three taxa (87\% of the total).

For zooplankton taxa, nMDS ordination (Fig. 3) and ANOSIM results (Table 2) showed greatest distances for samples belonging to each study season, as well as distinctive groupings for each lagoon, particularly in August. In pairwise comparisons and SIMPER analyses, the largest $\mathrm{R}$ values and dissimilarity rates also occurred between the Tancada and Clot lagoons and between seasons (Table 2). SIMPER analyses further showed that the largest contributions to dissimilarities among lagoons were due to differences in the abundance of 10 taxa. The copepod Canuella perplexa, polychaeta and bivalve larvae, and foraminifera were most abundant in the Tancada lagoon, followed by Encanyissada, and least abundant in Clot (6-19\%, 6-13\%, 8-13\%, and $5-13 \%$ of dissimilarities between lagoons, respectively for each taxa). Equally, the overall

Table 2. Results of 2-way ANOSIM and SIMPER analyses for phytoplankton and zooplankton assemblages based on dissimilarity matrices derived from taxa abundances (log $(x+1)$ transformation). In ANOSIM analyses, significant results are indicated in bold. $\mathrm{E}=$ Encanyissada $, \mathrm{C}=\mathrm{Clot}, \mathrm{T}=$ Tancada, $\mathrm{W}=$ winter, $\mathrm{S}=$ summer. Resultados del ANOSIM de dos vías para la comunidades de fitoplancton y zooplancton basados en matrices de disimilaridad derivadas de valores abundancias (transformados log ( $\mathrm{x}+1)$. Los resultados significativos se indican en negrita.

\begin{tabular}{|c|c|c|c|c|c|c|c|}
\hline \multicolumn{4}{|c|}{ Phytoplankton } & \multicolumn{3}{|c|}{ Zooplankton } & \multirow[b]{2}{*}{ Diss (\%) } \\
\hline & $\mathrm{R}$ & $p(\%)$ & Diss (\%) & & $\mathrm{R}$ & $p(\%)$ & \\
\hline Lagoon & 0.784 & 0.1 & & Lagoon & 0.848 & 0.1 & \\
\hline C-T & 1 & 0.2 & 54.57 & C-T & 0.914 & 0.1 & 50.81 \\
\hline C-E & 0.828 & 0.1 & 29.71 & C-E & 0.868 & 0.1 & 32.62 \\
\hline T-E & 0.578 & 0.2 & 37.47 & T-E & 0.847 & 0.1 & 41.72 \\
\hline $\mathrm{C}$ & & & 89.82 & $\mathrm{C}$ & & & 84.80 \\
\hline $\mathrm{E}$ & & & 85.36 & $\mathrm{E}$ & & & 81.22 \\
\hline $\mathrm{T}$ & & & 85.64 & $\mathrm{~T}$ & & & 74.58 \\
\hline Period & 0.960 & 0.1 & 34.69 & Period & 1 & 0.1 & 86.90 \\
\hline Feb & & & 87.67 & Feb & & & 80.64 \\
\hline Aug & & & 86.20 & Aug & & & 79.77 \\
\hline
\end{tabular}


abundance of indeterminate nauplii stages, was higher in the Tancada lagoon, and displayed similar numbers in the Clot and Encanyissada lagoons (14\% contributions to dissimilarities). In contrast, the abundance of branchiopoda (cladocera) tended to be higher in the Clot and Encanyissada lagoons and lowest in the Tancada (5$13 \%$ of dissimilarities). Seasonally, differences were due to higher numbers of copepod nauplii, copepodite of Calanipeda aequadulcis, polychaeta and bivalve larvae, and rotifera in winter (45\% of dissimilarities), and adult $C$. aequadulcis, and C. perplexa, and branchiopoda (cladocera), in summer (43\% of dissimilarities).

\section{Taxa-environment relationships}

The cumulative percentage variance of phytoplankton taxa composition was $47 \%$, and environmental variables explained up to $91 \%$ of the variability in taxon composition (both in the two first CCA axes). Three environmental variables were found to be significant for observed patterns, with salinity and temperature displaying the highest contributions (Fig. 4, Table 3).
For zooplankton, the cumulative percentage variance of taxa composition was $61 \%$, and the proportion of variability explained by environmental variables $85 \%$, only for the two first CCA axes. Although up to ten variables showed significant effects, only temperature and salinity explained over $20 \%$ of the variation in taxa composition (Fig. 4, Table 3).

Table 3. Variance explained by each significant environmental variable in CCA models for phytoplankton and zooplankton across lagoons. Varianza explicada por cada variable significativa en los modelos de CCA para fitoplancton y zooplancton de las lagunas.

\begin{tabular}{ll}
\hline & \% Variance explained \\
\hline Phytoplankton & Sal: 43.63 \\
& T $^{\circ}: 16.36$ \\
& N-NH $:$ : 7.27 \\
\hline & T $^{\circ} \mathbf{C}: 52.03$ \\
& Sal: 20.32 \\
& pH: 6.50 \\
& Phyto: 3.25 \\
& OM: 3.25 \\
Zooplankton & Plant bio: 2.43 \\
& DO: 2.43 \\
& Gravel: 1.62 \\
& Shore dist: 0.81 \\
\hline
\end{tabular}

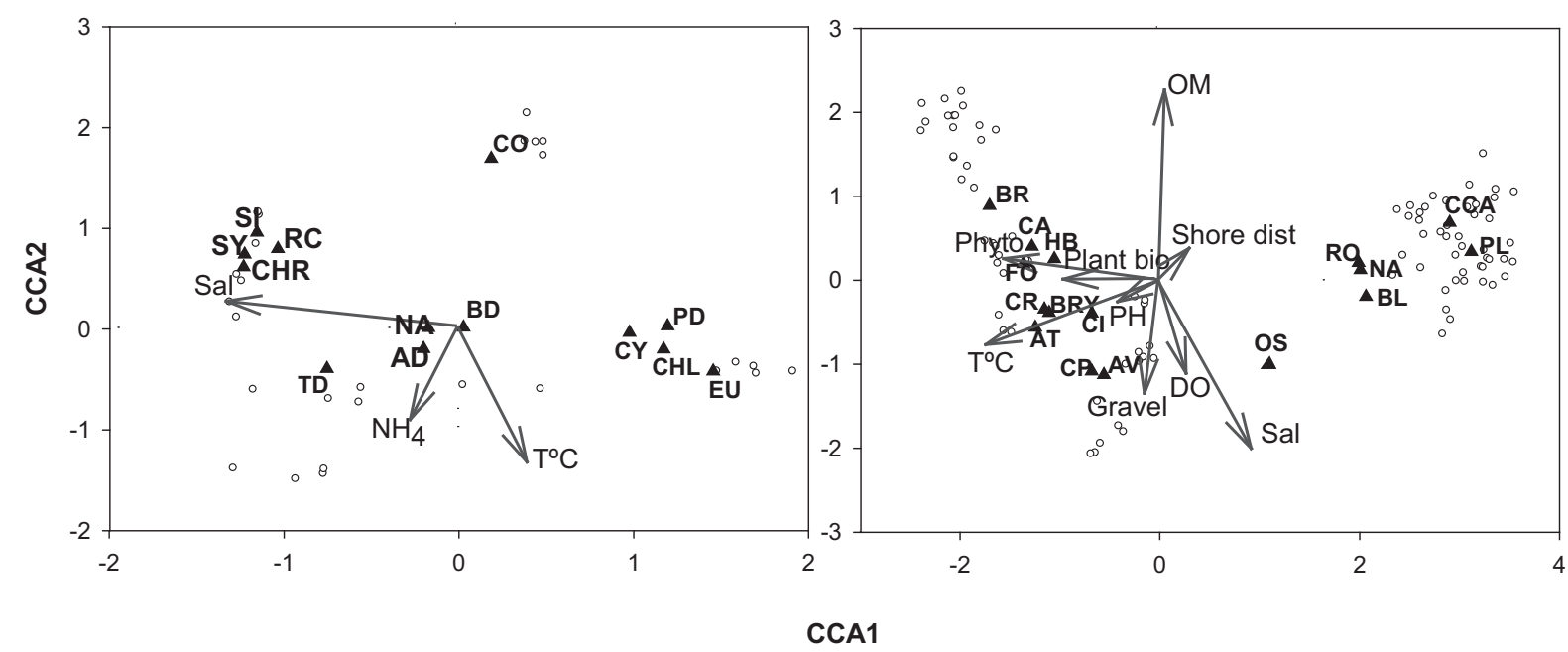

Figure 4. Canonical Correspondence Analyses (CCA) for investigated taxa of phytoplankton and zooplankton assemblages, and environmental variables. Species names as in Figure 2. Other unstated taxa are indicated. For phytoplankton/fitoplancton: $\mathrm{CO}=$ cocolitophorids; $\mathrm{SY}=$ Synurophyceae $\mathrm{CHR}=$ Chrysophyta $; \mathrm{RC}=$ resting cysts. For zooplankton/zooplancton: AT = Acartia tonsa; $\mathrm{CR}=$ Cletocampus retrogressus $; \mathrm{BRY}=$ Bryocamptus $\mathrm{sp} . ; \mathrm{BL}=$ bivalve larvae; $\mathrm{PL}=$ polychaete larvae; $\mathrm{HB}=\mathrm{Hydrobidae}$ spp., $\mathrm{OS}=$ ostracods; $\mathrm{RO}=$ rotifer; $\mathrm{CI}=$ ciliates. Análisis Canónico de Correspondencias (CCA) para las comunidades de fitoplancton y zooplancton y para las variables ambientales investigadas. Nomenclatura como en la Figura 2. Se indican otros taxones no especificados. 


\section{DISCUSSION}

This study shows that the abundance and composition of phytoplankton and zooplankton assemblages in coastal lagoons are strongly influenced by environmental conditions ( $>85 \%$ of explained variance) mostly related to the effects of the seasonal forcing (i.e., light and temperature) and to anthropogenic freshwater inflows. We found a temporal increase in the abundance of both phytoplankton and zooplankton from winter to summer as reported by other authors (e.g., Townsend et al., 1992; Gilabert, 2001). Our results confirm that salinity, is an important factor structuring both phytoplankton (Gasiūnaite $e t$ $a l ., 2005)$ and zooplankton communities (Brucet et al., 2009) in coastal lagoons and semienclosed estuaries. More importantly, we provide evidence of the impact of the current water management system and of the value of planktonic communities as indicators for the ecological assessment of coastal waters, even at low taxonomic resolution. Summer salinity variation among lagoons resulted in opposite effects on the two communities, with lower abundance of zooplankton and higher abundance of phytoplankton at greater freshwater inflows. Compared to values found 30 years ago, total phytoplankton abundance was about 50\% lower (Comín, 1984), whereas maximum abundances of total zooplankton were about 6 times higher than in past reports (Menéndez \& Comín, 1986). Although annual ranges of dissolved nutrient concentrations within the lagoons were comparable (min-max: 0-27 $\mu \mathrm{g} / 1 \mathrm{NO}_{3}, 0.2-4.7 \mu \mathrm{g} / \mathrm{PO}_{4}$, and 0.5-321.6 $\mu \mathrm{g} / \mathrm{l}$ $\mathrm{NH}_{4}$ in Comín, 1984; and 0.9-64 $\mu \mathrm{g} / \mathrm{l} \mathrm{NO} \mathrm{NO}_{3}, 1.3-$ $25 \mu \mathrm{g} / \mathrm{l} \mathrm{PO}_{4}$, and 11-284 $\mu \mathrm{g} / \mathrm{NH}_{4}$ in Prado et al., 2013a), current planktonic abundances may be explained by a sharp reduction in the discharge of particulate organic matter from rice fields into the lagoons following the construction of circumvallation channels, and to the reappearance of macrophyte communities (Prado et al., 2013a).

Even though the phytoplankton community in coastal lagoons is often characterized by euryhaline species (Badylak \& Phlips, 2004; Ayadi et $a l ., 2004)$, salinity oscillations were the most important factor accounting for observed patterns of taxa abundance and composition (accounting for ca. $44 \%$ of the variation) across the Clot, Encanyissada, and Tancada lagoons. In spite of being tolerant to a wide salinity range, different species or groups of taxa may have variable growth optima (e.g., Grzebyk \& Berland, 1996; Roubeix \& Lancelot, 2005) that may have prompted distinctive patterns of dominance along the study gradient, although some indirect effects of the freshwater inputs were also evidenced (see later). The study period accounted for $16 \%$ of the variation in the planktonic community and this is primarily attributable to increases in the availability of light for photosynthesis from winter to summer (Townsend et al., 1992). Bacillariophyceae were one of the commonest groups, with higher abundances in the Clot and Encanyissada lagoons during the summer period. Although this is a highly diverse group in both marine and freshwater environments (Round et al., 1990), in the lagoons it was represented mostly by benthic species that were probably resuspended from the sediment. This process, linked to freshwater discharge, may be particularly important for the functioning of the system during the winter period, when it is windier and the water column is subjected to strong mixing. Chlorophyceae, and to a lesser extent Cyanophyceae, and Euglenophyceae (all generally $<1 \%$ ) were also more abundant in the Clot lagoon during the summer period (as may occur in freshwater environments; Nicholls, 1976), and decreased in the Encanyissada and Tancada lagoon. These summer communities in the Clot were also similar to those reported $30 \mathrm{yr}$ ago by Comin (1984) during the freshwater discharge period. In contrast, Dinophyceae, showed the reverse pattern with higher abundances in the Tancada lagoon and Encanyissada lagoon, and lowest in the Clot $(53 \%, 13 \%$, and $1 \%$, respectively). This group commonly reaches its highest abundance and diversity in estuaries and coastal-waters, where there are prevalent human interactions with the marine environment (Fodor, 2014), and has commonly been found during long-term monitoring of the Ebro Delta Bays (M. Fernández, pers. communication), suggesting en- 
trance into the lagoons through the channels connecting the Encanyissada and Tancada to Alfacs Bay. Nanoflagellates (mostly Cryptophyceae) were more abundant at intermediate salinities (ca. $57 \%$ of the total phytoplankton in the Encanyissada, and 30-35\% in the Clot and Tancada lagoon), although they are usually common in marine waters (Cerino \& Zingone, 2013). Both dinoflagellates and nanoflagellates were more abundant in summer, as often reported in coastal waters beyond certain temperature threshold (Cerino \& Zingone, 2013; Fodor, 2014). In contrast, 30 years ago they were only common from February to April in the Tancada lagoon, and a single species of Dunaliella sp. (Chlorophyceae) tended to dominate the phytoplankton community within the lagoons at high winter salinities (Comín, 1984).

The abundance and community structure of zooplankton within the study lagoons was also found to be mostly associated with salinity and seasonal forcing (ca. $72.3 \%$ of the variation), with minor contributions of other commonly structuring variables, such as nutrients, phytoplankton, and plant biomass. These results confirm previous findings showing that salinity and temperature have a major role in shaping zooplankton assemblages in Mediterranean coastal lagoons (see Brucet et al., 2009; 2010), and further suggest the sensitivity of these communities to adverse global-warming scenarios (Schallenberg et al., 2003; Brucet et al., 2010). In particular, the effect of the salinity gradient has been proposed to cause a shift in the dominance of large filter-feeding cladoceran species (such as Daphnia spp.) at low salinities to dominance of copepods and small cladoceran species at higher salinities (Brucet et al. 2009; 2010; Jensen et al., 2010). In our study, the zooplankton community of the three lagoons was dominated by copepod life stages with lesser abundance of other taxa, especially during the winter when nauplii were most abundant. The calanoid copepod Calanipeda aequadulcis was the most widespread taxon across lagoons with more adults in summer and copepodits in winter, consistent with high abundance patterns 30 years ago (Menéndez \& Comín, 1986) and the osmoconformity of this species (Svetlichny et al., 2012). The second most abundant taxon, the harpacticoid copepod Canuella perplexa (not mentioned in previous reports by Menéndez \& Comín (1986)) was the main species responsible for the higher abundance of total zooplankton at greater salinities, in agreement with its wide distribution in coastal lagoons at salinities from 16-32 during the summer period (Ceccherelli \& Mistri, 1991). Other copepod species, such as the calanoid Acartia tonsa and the harpacticoids Cletocamptus retrogressus and Bryocamptus sp., were only present in marginal numbers but also showed higher summer abundances in the Encanyissada and Tancada lagoons, consistent with seasonal and salinity observations in other coastal lagoons (Lucena-Moya et al., 2010). In contrast, the cyclopoid Acanthocyclops vernalis (Menéndez \& Comín, 1986) was found in low numbers in the three study lagoons and had little influence in observed patterns. Cladocerans, which are a monophyletic group occurring primarily in freshwater (Forró et al., 2008) but which are also common in brackish environments such as coastal Mediterranean lagoons (Brucet et al., 2009), were least abundant in winter and in the polyhaline waters of the Tancada lagoon. Jensen et al., (2010) showed that at low salinities $(<1)$ both planktonic (free-swimming) and benthic (plant-associated) cladocerans occurred, whilst only benthic ones occurred at the highest salinity (ca. 4). Hence, it is possible that in summer, with salinities $\geq 4$ and high abundance of benthic macrophytes (Prado et al., 2013a), benthic species might have been predominant (with some exceptions such as Daphnia magna at salinities >10; Brucet et al., 2009), although confirmation would have required a higher level of taxonomic resolution than was feasible in our study. Other crustacean taxa, such as ostracoda, were present in low numbers throughout the study, consistent with the lack of mention of this group in other coastal Mediterranean lagoons (e.g. Brucet et al., 2009; 2010). Among other zooplankton groups, rotifers have been indicated to attain higher summer biomasses in Catalan lagoons (Badosa et al., 2007; Brucet et al., 2009), whereas we found the reverse pattern, with higher 
abundances in winter, particularly at lower salinities in the Clot lagoon. Although the causes of this pattern are unclear, it might be partly due to other non-investigated factors, such as lower rates of fish predation (consistent with the high fishing pressure locally; RodríguezCliment, 2015) compared to other studies (e.g., Badosa et al., 2007; Jensen et al., 2010), thus favoring the abundance of large vs. small size zooplankton. As in the 70s, the distribution of polychaeta and bivalve larvae displayed higher abundances in saltier lagoons during the summer period (Menéndez \& Comín, 1986). These taxa may enter the Tancada and in the Encanyissada lagoon through connections channels with the Alfacs Bay, where species such as Cerastoderma sp., Scrobicularia plana, and members of the Phyllodocidae are commonly found (Prado et al., 2014a). For foraminifera, higher numbers (absolute values) were also observed in summer in the Tancada lagoon, agreeing with the generally higher abundance and diversity of the group in marine environments (Murray, 1991) and the presence of connections with the sea. Other taxa, such as ciliates, were only present in small numbers and showed no variation along the salinity gradient, consistent with the apparent dominance of larger zooplankton and a clear-water state (Jensen et al., 2010).

To conclude, results from this study suggest that both temperature and altered salinity resulting from freshwater discharges are the two central factors controlling the abundance and composition of planktonic assemblages in the coastal lagoons studied. Differences among planktonic communities were particularly important in summer, the period of freshwater influence, and resulted in lower abundance of phytoplankton and higher abundance of zooplankton at greater salinities. Compared with community patterns observed 30 years ago, the greater differences in planktonic composition across lagoons can be explained by changes in the annual salinity oscillations from the $70 \mathrm{~s}$ (from ca. 1-2 to 17-23 in all the lagoons; Comín, 1984) to the present (3.6 to 11.6 in Clot, 12.5 to 27.1 in Encanyissada, and 18.6 to 28.1 in Tancada). Differences greater than two-fold in the abundance of planktonic communities across the salinity gradient may contribute to observed changes in the trophic ecology of resident fish (Prado et al., 2014b), and modify the functioning of the entire ecosystem through altered recycling efficiencies and contributions of primary producers to ecosystem fluxes (Prado $e t$ al., 2013b). Overall, we advise that the lagoons would benefit from a more natural hydrological regime, without riverine freshwater inflows and high summer salinities.

\section{ACKNOWLEDGEMENTS}

P. Prado was supported by a Beatriu de Pinós postdoctoral fellowship from the Catalonian Government (AGAUR). We are very grateful to Margarita Fernández for her help with identification of phytoplankton groups. We also thank L. Jornet and D. Mateu for their assistance with fieldwork. We are also grateful to Professor D. G. Mann for corrections of English language and valuable comments on the ms.

\section{REFERENCES}

AYADI, H., O. ABID, J. ELLOUMI, A. BOUAÏN \& T. SIME-NGANDO. 2004. Structure of the phytoplankton communities in two lagoons of different salinity in the Sfax saltern (Tunisia). Journal of plankton research, 26: 669-679.

BADYLAK, S. \& E.J. PHLIPS. 2004. Spatial and temporal patterns of phytoplankton composition in subtropical coastal lagoon, the Indian River Lagoon, Florida, USA. Journal of Plankton Research, 26: 1229-1247.

BADOSA, A., D. BOIX, S. BRUCET, R. LÓPEZFLORES, S. GASCÓN \& X.D. QUINTANA. 2007. Zooplankton taxonomic and size diversity in Mediterranean coastal lagoons (NE Iberian Peninsula): influence of hydrology, nutrient composition, food resource availability and predation. Estuarine, Coastal and Shelf Science, 71: 335-346.

BODEANU, N. 1993. Microalgal blooms in the Romanian area of the Black Sea and contemporary eutrophication conditions. In: Toxic phytoplankton blooms in the sea. Smayda T. J. \& Y. Shimizu 
(eds.): 203-209. Elsevier Science Publishers, Amsterdam.

BRUCET, S., D., BOIX, X.D. QUINTANA, E. JENSEN, L.W. NATHANSEN, C. TROCHINE, M. MEERHOFF, S. GASCÓN \& E. JEPPESEN. 2010. Factors influencing zooplankton size structure at contrasting temperatures in coastal shallow lakes: implications for effects of climate change. Limnology and Oceanography, 55: 1697-1711.

BRUCET, S., D., BOIX, S. GASCÓN, S. SALA, X.D. QUINTANA, A. BADOSA, M. SØNDERGAARD, T.L. LAURIDSEN \& E. JEPPESEN. 2009. Species richness of crustacean zooplankton and trophic structure of brackish lagoons in contrasting climate zones: North temperate Denmark and Mediterranean Catalonia (Spain). Ecography, 32: 692-702.

COMÍN, F.A. 1984. Características físicas y químicas y fitoplancton de las lagunas costeras, Encañizada, Tancada y Buda (Delta del Ebro). Oecologia Aquatica, 7: 79-162.

CECCHERELLI, V.U. \& M. MISTRI. 1991. Production of the meiobenthic harpacticoid copepod Canuella perplexa. Marine Ecology Progress Series, 68: 225-234.

CERINO, F. \& A. ZINGONE. 2013. A survey of cryptomonad diversity and seasonality at a coastal Mediterranean site. European Journal of Phycology, 41: 363-378.

FODOR, L. 2014. Dinoflagellate diversity and dynamics in Outer Oslofjorden as revealed by molecular methods. MSci Thesis in Marine Biology. University of Oslo, Norway.

FORRÓ, L., N.M. KOROVCHINSKY, A.A. KOTOV \& A. PETRUSEK. 2008. Global diversity of cladocerans (Cladocera; Crustacea) in freshwater. $\mathrm{Hy}$ drobiologia, 595: 177-184.

GASIŪNAITĖ, Z.R., A.C. CARDOSO, A.S. HEISKANEN, P. HENRIKSEN, P. KAUPPILA, I. OLENINA, R. PILKAITYT, I. PURINA, A. RAZINKOVAS, S. SAGERT \& H. SCHUBERT. 2005. Seasonality of coastal phytoplankton in the Baltic Sea: influence of salinity and eutrophication. Estuarine, Coastal and Shelf Science, 65: 239-252.

GILABERT, J. 2001. Seasonal plankton dynamics in a Mediterranean hypersaline coastal lagoon: the Mar Menor. Journal of Plankton Research, 23: 207217.

GRZEBYK, D. \& B. BERLAND. 1996. Influences of temperature, salinity and irradiance on growth of Prorocentrum minimum (Dinophyceae) from the
Mediterranean Sea. Journal of Plankton Research, 18: 1837-1849.

HART, R.C. 1988. Zooplankton feeding rates in relation to suspended sediment content: potential influences on community structure in a turbid tropical reservoir. Freshwater Biology, 19: 123-139.

HEATH, M.R. 2005. Changes in the structure and function of the North Sea fish food web, 19732000, and the impacts of fishing and climate. ICES Journal of Marine Science: Journal du Conseil, 62: 847-868.

IKEDA, T. 1985. Metabolic rates of epipelagic marine zooplankton as a function of body mass and temperature. Marine Biology, 85: 1-11.

JENSEN, E., S. BRUCET, M. MEERHOFF, L. NATHANSEN \& E. JEPPESEN. 2010. Community structure and diel migration of zooplankton in shallow brackish lakes: role of salinity and predators. Hydrobiologia, 646: 215-229.

KJERFVE, B. \& K.E. MAGILL. 1989. Geographic and hydrodynamic characteristics of shallow coastal lagoons. Marine geology, 88: 187-199.

KOROLEFF, F. 1977. Simultaneous persulfate oxidation of phosphorus and nitrogen compounds in water. In: Report of the Baltic Intercalibration Workshop. Annex Interim Commission for the Protection of the Environment of the Baltic Sea. Grasshoff, K (ed.): 52-53.

LOTZE, H.K., M. COLL \& J.A. DUNNE. 2011. Historical changes in marine resources, food-web structure and ecosystem functioning in the Adriatic Sea, Mediterranean. Ecosystems, 14: 198-222.

LUCENA-MOYA, P., R. ABRAÍN, I. PARDO, B. HERMIDA \& M. DOMÍNGUEZ. 2010. Invertebrate species list of coastal lagoons in the Balearic Islands. Transitional Waters Bulletin, 4: 1-11.

MENÉNDEZ, M. \& F.A. COMÍN. 1986. Variación estacional del zooplancton en las lagunas costeras del Delta del Ebro (NE. España). Oecologia Aquatica, 8: 47-50.

MURRAY, J.W. 1991. Ecology and palaeoecology of benthic foraminifera. Routledge. London and New York.

NICHOLLS, K.H. 1976. The phytoplankton of the Kawartha lakes. The Kawartha lakes water management study-water quality assessment (19721976). Ministry of environment Report. Toronto, USA.

NUCCIO, C., C., MELILLO, L. MASSI \& M. INNAMORATI. 2003. Phytoplankton abundance, 
community structure and diversity in the eutrophicated Orbetello lagoon (Tuscany) from 1995 to 2001. Oceanologica Acta, 26: 15-25.

PÉREZ-RUZAFA, A., C. MARCOS, I.M. PÉREZRUZAFA \& M. PÉREZ-MARCOS. 2011. Coastal lagoons: "transitional ecosystems" between transitional and coastal waters. Journal of Coastal Conservation, 15: 369-392.

PRADO, P., N. CAIOLA \& C. IBÁÑEZ. 2013a. Spatio-temporal patterns of submerged macrophytes in three hydrologically altered Mediterranean coastal lagoons. Estuaries and Coasts, 36: 414-429.

PRADO, P., N. CAIOLA, C. IBÁÑEZ, E. REYES. 2013b. Evaluation of seasonal variability in the food-web properties of coastal lagoons subjected to contrasting salinity gradients using network analyses. Ecological Modeling, 265: 180-193.

PRADO, P., N. CAIOLA \& C. IBÁÑEZ. 2014a. Freshwater inflows and seasonal forcing strongly influence macrofaunal assemblages in Mediterranean coastal lagoons. Estuarine Coastal and Shelf Science, 147: 68-77.

PRADO, P., C. VERGARA, N. CAIOLA \& C. IBÁÑEZ. 2014b. Influence of salinity regime on the food-web structure and feeding ecology of fish species from Mediterranean coastal lagoons. Estuarine Coastal and Shelf Science, 139: 1-10.

RIGOLLET, V., A. SFRISO, A. MARCOMINI \& M.L. DE CASABIANCA. 2004. Seasonal evolution of heavy metal concentrations in the surface sediments of two Mediterranean Zostera marina L. beds at Thau lagoon (France) and Venice lagoon (Italy). Bioresource technology, 95: 159-167.

RODRÍGUEZ-CLIMENT, S.R. 2015. Assessing the impacts of human activities on the fish assemblages from the Ebro Delta coastal lagoons: towards a sustainable management model. $\mathrm{PhD}$ Thesis. Universitat de Barcelona.
ROUBEIX, V. \& C. LANCELOT. 2008. Effect of salinity on growth, cell size and silicification of an euryhaline freshwater diatom: Cyclotella meneghiniana Kütz. Transitional waters bulletin, 2: 31-38.

ROUND, F.E., R.M. CRAWFORD, \& D.G. MANN. 1990. The diatoms: biology and morphology of the genera. University Press. Cambridge, UK.

SCHALLENBERG, M., C.J. HALL \& C.W. BURNS. 2003. Consequences of climate-induced salinity increases on zooplankton abundance and diversity in coastal lakes. Marine Ecology Progress Series, 251: 181-189.

SEI, S., G. ROSSETTI, F. VILLA \& I. FERRARI. 1996. Zooplankton variability related to environmental changes in a eutrophic coastal lagoon in the Po Delta. In: Coastal Lagoon Eutrophication and Anaerobic Processes (CLE AN.): 45-55. Springer, Netherlands.

SOUCHU, P., B. BEC, V.H. SMITH, T. LAUGIER, A. FIANDRINO, L. BENAU, V. ORSONI, Y. COLLOS \& A. VAQUER. 2010. Patterns in nutrient limitation and chlorophyll a along an anthropogenic eutrophication gradient in French Mediterranean coastal lagoons. Canadian Journal of Fisheries and Aquatic Sciences, 67: 743-753.

SOURNIA, A. (ed.) 1978. Phytoplankton manual. Monographs on oceanographic methodology 6 . UNESCO. Paris, France.

SVETLICHNY, L., HUBAREVA, E. \& A. KHANAYCHENKO. 2012. Calanipeda aquaedulcis and Arctodiaptomus salinus are exceptionally euryhaline osmoconformers: evidence from mortality, oxygen consumption, and mass density patterns. Marine Ecology Progress Series, 470: 15-29.

TOWNSEND, D.W., M.D. KELLER, M.E. SIERACKI \& S.G. ACKLESON. 1992. Spring phytoplankton blooms in the absence of vertical water column stratification. Nature, 360 (6399): 59-62. 